\title{
SOCIAL INCLUSION OF ROMA YOUTH IN THE CONTEXT OF RISK BEHAVIOUR Katarína Šiňanská ${ }^{1}$, Lucia Tóthová ${ }^{2}$
}

\begin{abstract}
A specific feature of the Roma community is socialization on two levels - integration into their own Roma community, and integration into the majority of society. This paper focuses on a specific group of adolescents, namely the Roma youth, while the social inclusion of this youth is considered by authors an important phenomenon, from which the life of the individual further unfolds, as well as risk behaviour manifested in it, in which adolescents participate to a greater extent compared to other developmental stages.

On the empirical level, this paper focuses on the need for social inclusion and achieved social inclusion of respondents. The research sample consisted of Roma youth living in marginalized settlements in eastern Slovakia, and respondents living outside of Roma settlements. The result was the finding that these groups of adolescents do not differ in the need of social inclusion, but the achieved social inclusion demonstrated more in Roma adolescents living outside of the settlements. By comparing these two values, it has been shown that Roma adolescents living in settlements feel pushed away, unworthy of the attention of others, and underestimated. On the other hand, Roma living outside of settlements feel harassed, oppressed, and subjected to group pressure and social conventions.
\end{abstract}

UDC Classification: 304, DOI: 10.12955/cbup.v7.1431

Keywords: adolescence, risk behaviour, Roma community, social inclusion

\section{Introduction}

Risk behaviour is currently a concept involving a number of different categories of behaviour that, according to Širůček et al. (2007) and Lichner and Šlosár (2017), cause health, social or psychological risk to the individual or their social environment. Such risk behaviour usually occurs during adolescence, which is very specific and has blatant elements compared to other developmental stages.

In Slovakia, a large number of adolescents are formed by individuals originating from the Roma community, while the Roma belong among the most common ethnic group in Slovakia. Creţan and Turnock (2008) assume that the largest portion of Roma in Europe are in Macedonia (11\%), Romania (10\%) and Slovakia (10\%). Bobakova et al. (2015) mentions in their publication that more than 400,000 Roma live in Slovakia, what represents $7.5 \%$ of the Slovak population. It is therefore necessary to focus even on these adolescents which come from a minority culture that is different from the rest of the population.

On the basis of this, the authors focused on one of the aspects influencing the risk behaviour of Roma adolescents, lack of social inclusion. Adolescent age is sensitive to social interaction. Specifically, Roma young people who tend to be excluded from the majority due to their ethnicity, are also excluded from their own community. The aim of this paper was to reveal the social affiliation of Roma adolescents, with an emphasis on the desired affiliation and the achieved affiliation and the comparison of this data, which made it possible to discover risk groups of Roma adolescents in the context of developing various forms of risk behaviour.

\section{Theoretical background}

The term adolescence comes from the Latin word "adolescere", which means growing up, maturing, developing, but also rise and gaining strength. Perhaps that is why its meaning is often confused with the concept of adolescence as a whole, or is used as a generic term for adolescents or youth (Macek, 1999). The time period of adolescence differs from author to author. In European psychology, adolescence is separated from pubescence, which lasts from 11 to 15 years. Thus, adolescence dates from 15 to 20 up to 22 years of age. Its beginning is associated with the end of sexual maturation and full reproductive maturity. During its course, physical growth is usually finished (Langmeier, \& Krejčířová, 1998; Vágnerová, 2000). Periodization by authors Žiaková, Barinková, Šiňanská (2017) defines adolescence as a whole period between childhood and adulthood, and lasts from 10 to 20 years or longer. According to Macek (2003), the social aspect of identity is important, social inclusion and satisfaction of need to belong somewhere. An adolescent usually completes school at this stage, leaves the family environment, enters into employment, sets goals, plans and new roles for the future (Džambazovič, 2018).

\footnotetext{
${ }^{1}$ Department of Social Work, Faculty of Arts, Pavol Jozef Šafárik University in Košice, katarina.sinanska@upjs.sk

${ }^{2}$ Department of Social Work, Faculty of Arts, Pavol Jozef Šafárik University in Košice, lucia.tothova1@upjs.sk
} 
The period of adolescence is a period in which young people participate in risk behaviour to a greater extent compared to other developmental stages. Pound and Campbell (2015) have identified several theories that explain the development of risk behaviour. According to them, risk behaviour occurs for example as the:

- result of lack of social inclusion,

- result of isolation from the majority society,

- response to social constraints,

- resistance,

- aspect of adolescent development.

In this context, authors specifically focus on the lack of social inclusion as one of the aspects affecting the presence of risk behaviour in adolescence. Indeed, in this development period, social interactions become more important than in any other developmental period (Crone, \& Dahl, 2012). Three important types of peer relationships are identified in adolescence:

- dyadic friendships,

- small groups of friends who operate at different levels of proximity,

- crowds that serve to organize and categorize social worlds of adolescents in the context of school and surroundings (Brown, 2004; Horn, 2003).

Mutual relationships between youth play an important role in adolescent social and cognitive development. Social exclusion or rejection by peers represents a particularly powerful form of social interaction (Williams, 2007), which may affect lives and the future trajectory of adolescents, leading to social isolation, anxiety and depression (Leary et al., 2006), may negatively affect individual and interpersonal behaviour (Ayduk et al., 2008; Baumeister et al., 2005; Twenge et al., 2002), may lead to anti-social behaviour (Adams et al., 2011), and provides a link to the involvement of adolescents in risk behaviour (Dishion, \& Owen, 2002; La Greca et al., 2001; Simons-Morton et al., 2005). Sampson and Laub (1997) explain that adolescents with threatened or unmet specific needs may engage in risk activities or behaviour in order to gain the recognition of peers or to form an opposing identity to the identity of their "rejectors".

Exclusion from social groups occurs when criteria for membership are challenged, when the group's identity or its functioning is threatened. Exclusion based on ethnicity, culture, sexual orientation or gender is common (Hitti et al., 2011). In relation to Roma adolescents, exclusion based on culture or nationality can increase the pressure between assimilation and acculturation, and has implications for the preservation of cultural identity (D'Augelli, 1998). Here it is important to mention the parallel of Roma socialization that takes place, so to speak, on two levels. Roma are integrated not only into their own community in which they live, but also into the majority society they are part of.

Youths from Roma settlements often encounter misunderstanding and discrimination when socializing in the majority society (Rus, \& Zatreanu, 2009). The reason can be the specific way of life of the Roma, which reflects their historical and social development. The life experiences of their ancestors, the way of thinking, the norms of behaviour that they have created either to each other or to the majority, affect their slower integration. The Roma brought other customs, traditions to the majority society, recognize other values and morals, which may be contrary to the values and morals of the majority society. As a result of this, the feeling of inferiority often appears in the Roma (Daňo, 2003).

The individual socializes and integrates into society through the family, adopting social norms, values and patterns of behaviour for his/her own. However, many Roma families are incomplete. There are many anti-social behaviours and actions. Not only parents, but even children are subjected to alcohol, smoking and drugs, what is related to various negative consequences and conflicts (Ďuričeková, 2000). Infidelity, promiscuity, mothers having children with different men, children not knowing their father, occurs more and more in Roma settlements. Roma couples marry very young and their age at the birth of a firstborn is decreasing. Such immature parents lack the knowledge to properly raise a child (Horňák, 2008). Davidová et al. (2010) state that the inclusion of Roma, their status in society, as well as social status are changing through generational developments. Since the 1990s, Roma have begun to divide themselves as successful and unsuccessful, on the basis of which they are often assessed and defined. Some Roma with a higher education tend not to communicate and not to 
identify themselves with Roma from the lower class. As a result of this, the Roma can develop defense mechanisms, in the form of various forms of risk behaviour.

Djonic et al. (2013) or Kabakchieva et al. (2002) describe sexual risk behaviour, Gerevich et al. (2013) discusses the use of tobacco, illegal drugs, alcohol intoxication in Roma adolescents. In addition, unpredictable and aggressive behaviour, truancy, theft and other socially undesirable symptoms are common in Roma adolescents (Liba, 2008) and there are health problems that are associated with poor eating habits and an unhealthy lifestyle (European Union, 2014).

\section{Selected results of empirical study}

Methodology and characteristics of the file

On the empirical level, the paper focuses on the need for desired affiliation and achieved affiliation of respondents, using the Social affiliation questionnaire (Kollárik, 2008). The method consists of two separate parts, each of which consists of 30 statements that can be answered by the yes or no alternative. The score obtained for each questionnaire provides a separate indication of the need for desired affiliation and achieved affiliation, but it also allows mutual comparison of these two values.

Less than half of all Roma live scattered among the majority population; the rest live either in urban concentrations, on the outskirts of towns or villages, or in separate or segregated Roma settlements. Especially these are characterized by degrading living conditions, poor housing often without sewerage and running water, and being cut off from transport networks. Present is a low level of education that leads to a low employment rate and results in high dependence of one generation to another (Bobakova et al., 2015). The research sample thus consisted of Roma youth aged 13 to 26 years $(\mathrm{N}=111)$, of whom 61 adolescents lived in marginalized settlements in eastern Slovakia, 50 respondents came from outside of Roma settlements, and these groups were statistically compared.

Results

Tab. 1 shows results of the Mann-Whitney U test, through which differences in the desired affiliation among young Roma living in the Roma settlement and those living outside of the Roma settlement were identified and compared. They point out that the compared groups of adolescents do not differ in the desired affiliation, as pointed out by the scores achieved, as well as the $\mathrm{p}(\alpha)$ value, which does not reach statistical significance. The desired affiliation nevertheless diagnoses the motivational component of affiliation.

Roma have a tendency to stay marginalized due to their desire to preserve their traditional values (Crețan, \& Turnock, 2008). Roma living in the Roma settlement have many social contacts. They grow up in multi-generation families that are of great importance to them. These family ties can affect that the Roma youth living in the Roma settlement do not feel lonely and the need for social inclusion is at a comparable level to that of adolescents living outside of the Roma settlement.

\begin{tabular}{|l|c|c|c|c|}
\hline Table 1: Desired affiliation & $\mathbf{N}$ & $\mathbf{X}$ & $\mathbf{Z}$ & $\mathbf{p}(\boldsymbol{\alpha})$ \\
\hline Residence & 61 & 59.41 & \multirow{2}{*}{-1.239} & 0.215 \\
\hline Adolescents living in Roma settlement & 50 & 51.84 & \\
\hline Adolescents living outside of Roma settlement &
\end{tabular}

Among respondents living in and outside of the Roma community, there were statistically significant differences in achieved affiliation, which was more demonstrated in Roma adolescents living outside of settlements (Table 2). The achieved affiliation, based on the individual's subjective testimony, monitors contact making activities, adaptability and speed of social adaptation in new situations. Therefore, it can be stated that Roma adolescents from Roma settlements have a bigger problem with the implementation of these activities.

\begin{tabular}{|c|c|c|c|c|}
\hline Residence & $\mathbf{N}$ & $\overline{\mathbf{X}}$ & $\overline{\mathbf{Z}}$ & $\mathrm{p( \alpha )}$ \\
\hline Adolescents living in Roma settlement & 61 & 38.66 & \multirow{2}{*}{-6.316} & \multirow{2}{*}{0.001 ** } \\
\hline Adolescents living outside of Roma settlement & 50 & 77.16 & & \\
\hline
\end{tabular}


Tab. 3 shows a comparison of the achieved score within the desired affiliation and the achieved affiliation. It has been demonstrated that in adolescents from the Roma settlement, the desired affiliation is greater than the achieved affiliation. It is therefore likely that these individuals feel pushed away, not accepted by the social group, they feel that they are not worthy of the attention of others. In contrary, adolescents coming from outside of the Roma community had a lower need for social inclusion than the level of achieved affiliation. This difference points out that adolescents living outside of the Roma settlement may feel harassed, oppressed, subject to the influence of the group and the influence of social conventions, they do not want to offend anyone, or do not have enough strength to show their feelings, and strong conformity can be manifested.

\begin{tabular}{|c|c|c|c|}
\hline Residence & Achieved affiliation & Desired affiliation & Difference \\
\hline Adolescents living in Roma settlement & 38.66 & 59.41 & -20.75 \\
\hline Adolescents living outside of Roma settlement & 77.16 & 51.84 & 25.32 \\
\hline
\end{tabular}

Source: Authors

Lightfoot (1997) distinguishes normative, exploratory, or transient risk (e.g. experimenting with alcohol) from activities that endanger health, are destructive or pathogenic (e.g. dependence on crack). Those who engage in serious or persistent risk activities belong to marginal and relatively isolated social groups. Groups whose risk behaviour is at limit will have a high degree of internal coherence and low throughput for a larger social network, while groups involved in normative risk may also be internally coherent, but will have greater throughput for wider social networks. The author further argues that persistent or serious risk is more likely when a person is isolated from the conventional society. This justifies the authors' orientation towards the social inclusion of Roma adolescents.

\section{Conclusion}

Adolescence is a period in which there is a general change in personality, it represents a significant psychosocial phenomenon. Life events appear in new optics. It is typical for adolescents to cope even with developmental natural complex tasks, which also include social inclusion issues. Adolescence is the process of preparing for adulthood, which depends on the immediate surroundings. The adolescent aims to achieve his/her own place in society, that is, their social status and role in it. However, he/she needs to meet his/her needs and demands to the right extent, and at the right time and space, and that his/her rights are respected. Roma youth have this whole process complicated by the fact that they come from a community that often has different habits and professes other values. Life in the Roma settlement is different to the way of life of youth in the majority society. If the aforementioned process of satisfaction is disturbed, one of the manifestations is a higher rate of adolescent risk behaviour.

In the emergence of risk behaviour, we are talking about its multifactorial conditionality, that is, it is influenced by various circumstances and stressful situations that the individual is experiencing and with which he/she cannot cope. Given that it is necessary to identify the phenomena that encourage the emergence of such behaviour, this paper focused on the social inclusion of Roma adolescents as one such factor. Results of the empirical study show that the desired affiliation did not differ significantly among the selected groups of Roma adolescents; however, the difference occurred in the achieved affiliation, which was more demonstrated among Roma adolescents living outside of settlement. However, the most important result was obtained by comparing these two values. Despite the fact that adolescents from the Roma settlement do not feel accepted by social groups from the majority society and adolescents living outside of the Roma settlement, on the other hand, they are subject to group influence to the intensity of conformity, and both groups represent risk groups in the context of developing various forms of risk behaviour. What forms and to what extent they occur in these groups will be the objective of further empirical studies by the authors.

These findings open up the scope for work in helping professionals, including social workers. It is true that in Slovak conditions the term social work is most often associated with the Roma population as a target group. However, these research outputs point to:

1. specific areas of social work (risk behaviour issues),

2. specific risk groups (Roma adolescents living in Roma settlement and adolescents living outside of Roma settlement),

3. factors contributing to the development of risk behaviour (social inclusion). 


\section{Acknowledgements}

This paper was created as part of the scientific research task Vega 1/0285/18 entitled "Risk behaviours of adolescents as clients of social work due to their loneliness".

\section{References}

Adams, B. D. et al. (2011). Understanding the process of radicalization: review of the empirical literature. Toronto: Human System.

Ayduk, O., Gyurak, A., \& Luerssen, A. (2008). Individual differences in the rejection-aggression link in the hot sauce paradigm: the case of rejection sensitivity. Journal of Experimental Social Psychology, 44(3), 775-782. https://doi.org/10.1016/j.jesp.2007.07.004

Baumeister, R. F. et al. (2005). Social exclusion impairs self-regulation. Journal of Personality and Social Psychology, 88(4), 589-604. http://dx.doi.org/10.1037/0022-3514.88.4.589

Bobakova, D. et al. (2015). Differences between Roma and non-Roma in how social support from family and friends helps to overcome health care accessibility problems. International Journal for Equity in Health, 14(1). https://doi.org/10.1186/s12939-015-0165-z

Brown, B. (2004). Adolescents' relationships with peers. In: R. M. Lerner, \& L. Steinberg (Eds.). Handbook of adolescent psychology (2nd ed., pp. 363-394). New York: Wiley. https://doi.org/10.1002/9780471726746.ch12

Creţan, R., \& Turnock, D. (2008). Romania's Roma population: from marginality to social integrations. Scottish Geographical Journal, 124(4), 274-299. https://doi.org/10.1080/14702540802596608

Crone, E. A. \& Dahl, R. E. (2012). Understanding adolescence as a period of social-affective engagement and goal flexibility. Nature Reviews. Neuroscience, 13(9), 636-650. https://doi.org/10.1038/nrn3313

D’Augelli, A. (1998). Developmental implications of victimization of lesbian, gay and bisexual youths. In: G. Herek (Ed.). Stigma and sexual orientation: understanding prejudice against lesbians, gaymen, and bisexuals (pp. 187-210). Thousand Oaks: Sage. http://dx.doi.org/10.4135/9781452243818.n9

Daňo, J. (2003). Negatívne využívaný vol’ný čas rómskych detí - základný kriminogénny faktor [Negatively used free time of Roma children - basic criminogenic factor]. In: P. Ružbarský. Telesná výchova a šport v tretom tisicročí (pp. 680-685). Prešov: Prešovská univerzita v Prešove, Fakulta humanitných a prírodných vied.

Davidová, E. et al. (2011). Kvalita života a sociální determinanty zdraví u Romu v České a Slovenské republice [The quality of life and social determinants of health among the Roma in the Czech and Slovak Republics]. Praha: Triton.

Dishion, T. J., \& Owen, L. D. (2002). A longitudinal analysis of friendships and substance use: bidirectional influence from adolescence to adulthood. Development Psychology, 38(4), 480-491. http://dx.doi.org/10.1037/11855-009

Djonic, D. et al. (2013). HIV-related risk behaviors among Roma youth in Serbia: results of two community-based surveys. The Journal of Adolescent Health: Official Publication of the Society for Adolescent Medicine, 52(2), 234-240. https://doi.org/10.1016/j.jadohealth.2012.05.012

Duričeková, M. (2000). Edukácia rómskych žiakov [Education of Roma pupils]. Prešov: Metodické centrum.

Džambazovič, R. (2018). Neskorá mladost'. Nový generačný model prechodu do dospelosti a jeho príčiny [Late youth. A new generational model of the transition to adulthood and its causes]. In: B. Balogová, \& M. Hamadej (Eds.). Aktuálne oblasti spoločenskovedného výskumu (pp. 17-29). Prešov: Prešovská univerzita v Prešove.

European Union. (2014). Roma Health Report. Health status of the Roma population. Data collection in the Member States of the European Union. European Union. http://dx.doi.org/10.2772/3140

Gerevich, J. et al. (2010). Substance use in Roma and non-Roma adolescents. The Journal of Nervous and Mental Disease, 198(6), 432-436. https://doi.org/10.1097/NMD.0b013e3181e07d51

Hitti, A., Mulvey, K. L., \& Killen, M. (2011). Social exclusion in adolescence. In: Levesque, R. J. R. (Eds). Encyclopedia of adolescence (pp. 2783-2792). New York: Springer. https://doi.org/10.1007/978-1-4419-1695-2

Horn, S. S. (2003). Adolescents' reasoning about exclusion from social groups. Developmental Psychology, 39, 71-84. http://dx.doi.org/10.1037/0012-1649.39.1.71

Horňák, L. (2005). Rómsky žiak v škole [Roma pupil in school]. Prešov: PF PU v Prešove.

Kabakchieva, E. et al. (2002). High levels of sexual HIV/STD risk behaviour among Roma (Gypsy) men in Bulgaria: patterns and predictors of risk in a representative community sample. International Journal of STD \& AIDS, 13(3), 184-191. https://doi.org/10.1258/0956462021924893

Kollárik, T. (2008). Dotazník sociálnej začlenenosti. Príručka [Social affiliation questionnaire. Guide.]. Bratislava: Psychodiagnostika, a.s.

La Greca, A. M., Prinstein, M. J., \& Fetter, M. D. et al. (2001). Adolescent peer crowd affiliation: linkages with health-risk behaviors and close friendships. Journal of Pediatric Psychology, 2001, 26(3), 131-143.

https://doi.org/10.1093/jpepsy/26.3.131

Langmeier, J., \& Krejčírová, D. (1998). Vývojová psychologie [Developmental pychology]. Praha: Grada.

Leary, M. R., Twenge, J. M., \& Quinlivan, E. (2006). Interpersonal rejection as a determinant of anger and aggression. Personality and Social Psychology Review, 10(2), 111-132. http://dx.doi.org/10.1207/s15327957pspr1002_2 
Liba, J. (2008). Škola v prevencii sociálno-patologických javov u žiakov zo sociálne znevýhodněného a výchovne menej podnětného prostredia [School in prevention of social-pathological phenomena in pupils from socially-disadvantaged and educationally less inspiring environment]. School and Health, 21(3), 123-130.

Lichner, V., \& Šlosár, D. (2017). Problematické použivanie internetu u adolescentov v kontextoch teórie a praxe sociálnej práce [Problematic internet use among adolescents in contexts of a theory and practice of the social work]. Košice: FF UPJŠ. Lightfoot, C. (1997). The culture of adolescent risk-taking. New York: Guilford Press.

Macek, P. (1999). Adolescence. Psychologické a sociální charakteristiky dospívajících [Adolescence. The psychological and social characteristics of adolescents]. Praha: Portál.

Macek, P. (2003). Adolescence [Adolecence]. Praha: Portál.

Pound, P. \& Campbell, R. (2015). Locating and applying sociological theories of risk-taking to develop public health interventions for adolescents. Health Sociology Review, 24(1), 64-80. https://doi.org/10.1080/14461242.2015.1008537

Rus, C., \& Zatreanu, M. (2009). Education of Roma children in Europe. Council of Europe Publishing.

Sampson, R. J., \& Laub, J. H. (1997). A Life-Course Theory of Cumulative Disadvantage and the Stability of Delinquency. New Brunswick: N. J. Transaction Publishers.

Simons-Morton, B. et al. (2005). The Observed Effects of Teenage Passengers on the Risky Driving Behavior of Teenage Drivers. Accident; Analysis and Prevention, 37(6), 973-982. https://doi.org/10.1016/j.aap.2005.04.014

Širůček, J., Širůčková, M., \& Macek, P. (2007). Sociální opora rodičů a vrstevníků a její význam pro rozvoj problémového chování v adolescenci [Parents' and friends' social support impact on problem behavior in adolescence]. Československá psychologie, 51(5), 476-488.

Twenge, J. M., Catanese, K. R., \& Baumeister, R. F. (2002). Social exclusion causes self-defeating behavior. Journal of Personality and Social Psychology, 83(3), 606-615. http://dx.doi.org/10.1037/0022-3514.83.3.606

Vágnerová, M. (2000). Vývojová psychologie. Dětství, dospělost, stáří [Developmental psychology. Childhood, adulthood, old age]. Praha: Portál.

Williams, K. D. (2007). Ostracism. Annual Review of Psychology, 58, 425-452.

https://doi.org/10.1146/annurev.psych.58.110405.085641

Žiaková, E., Barinková, K., \& Šiňanská, K. (2017). Purpose in life for adolescents with oncological diseases. In: M. Mollaoglu (Ed.). Well-being and quality of life. Medical perspective (pp. 133-146). Rijeka: InTechOpen. http://dx.doi.org/10.5772/68001 